\title{
SELF-MEDICATION OF ABORTIFACIENT AGENT AND ITS IMPACT ON WOMEN'S HEALTH- AN EXPERIENCE IN A GOVERNMENT MEDICAL COLLEGE OF WEST BENGAL
}

\author{
Ratan Chandra Mandal'1, Dipak Mandi², Debasish Bhar ${ }^{3}$, Chinmoy Mahapatra ${ }^{4}$, Kinkar Singh ${ }^{5}$
}

${ }_{1}^{1}$ Associate Professor, Department of Obstetrics and Gynaecology, Midnapore Medical College and Hospital, West Bengal, India.

${ }^{2}$ Associate Professor, Department of Obstetrics and Gynaecology, Burdwan Medical College, West Bengal, India.

${ }_{3}^{3}$ Associate Professor, Department of Anaesthesiology, Midnapore Medical College and Hospital, West Bengal, India.

${ }_{4}^{4}$ RMO-Cum-Clinical Tutor, Department of Obstetrics and Gynaecology, Midnapore Medical College and Hospital, West Bengal, India. ${ }_{5}^{5}$ Assistant Professor, Department of Obstetrics and Gynaecology, Midnapore Medical College and Hospital, West Bengal, India.

\section{ABSTRACT}

\section{BACKGROUND}

Self-medication or medication by untrained person for termination of unwanted pregnancy is commonly practiced among women of child bearing age group. This study was undertaken to observe the consequences of self-medication of abortifacient agent on women's health reporting to a Government Medical College.

\section{MATERIALS AND METHODS}

This is an observational study conducted at Midnapore Medical College from January 2016 to June 2017. After applying inclusion and exclusion criteria, 102 women were selected with respect to age, parity, period of gestation, clinical features at presentation, ultrasonography findings, complications and management they received. Analysis was also done with respect to surgical interventions, need for blood transfusion and maternal mortality.

\section{RESULTS}

In this study, 77 cases (75.4\%) were diagnosed as incomplete abortion (8 cases clinically and 69 cases ultrasonographically). 15 cases (14.7\%) of complete abortion, 5 cases (4.9\%) of missed abortion, 3 cases $(2.9 \%)$ of live gestation and 2 cases $(1.9 \%)$ of ruptured ectopic pregnancy were recorded. 15 cases $(14.7 \%)$ received blood transfusion and 2 cases $(2 \%)$ required intensive care unit (ICU) admission. Fortunately, no maternal death was reported in the study group.

\section{CONCLUSION}

Reproductive health protection and care is every woman's right. Awareness on contraception is must for all. This study shows urgent need for legislation and restriction of drugs used for medical termination of pregnancy. Availability of abortifacient drugs directly from hospital/ practitioners who are qualified under Medical Termination of Pregnancy (MTP) Acts may reduce complication of these drugs.

\section{KEY WORDS}

Self-Medication, Abortifacient, Abortion.

HOW TO CITE THIS ARTICLE: Mandal RC, Mandi D, Bhar D, et al. Self-medication of abortifacient agent and its impact on women's health- an experience in a Government Medical College of West Bengal. J. Evolution Med. Dent. Sci. 2018;7(25):2954-2956, DOI: $10.14260 /$ jemds/2018/665

\section{BACKGROUND}

Induced abortion is a voluntary termination of pregnancy before the period of viability. Abortions are performed for various indications that include social, economic or emotional reasons. In India abortion facility is available legally under the Medical Termination of Pregnancy (MTP) Act 1971. As per this act, MTP by medications can only be performed by gynaecologists and registered medical practitioners (RMP) recognised for performing MTPs up to 49 days since first day of last menstrual period (LMP).[1,2] Unfortunately, in India a large portion of women who want to terminate pregnancy use unsafe measure.

'Financial or Other Competing Interest': None.

Submission 02-05-2018, Peer Review 02-06-2018,

Acceptance 08-06-2018, Published 18-06-2018.

Corresponding Author:

Dipak Mandi,

C/o. Lakshmi Ram Soren,

Kuikota Adivasipara, P. O. Midnapore,

Dist. Paschim Medinipur-721101

West Bengal, India.

E-mail: dr.dipak.mandi@gmail.com

DOI: $10.14260 /$ jemds $/ 2018 / 665$

\section{(c) $(1) \ominus$}

The World Health Organisation (WHO) defines unsafe abortion as a procedure for terminating an unwanted pregnancy either by persons lacking the necessary skills or in an environment lacking minimal medical standards or both. ${ }^{[3]}$ Antiprogesterone drugs such as mifepristone (RU 486) and prostaglandins like misoprostol have been approved by United States Food and Drugs Administration (USFDA) for medical abortion. ${ }^{[4]}$ WHO recommendations on medical abortion are restricted to early first trimester (up to 63 days since first day of LMP).[5] The medical abortion carries a very high rate of success (93-98\%), if they are used judiciously such as after properly assessing the gestational age as well as health of the patient.[6,7] Federation of Obstetrics and Gynaecological Societies of India (FOGSI) recommends close monitoring on distribution of these drugs and medical professional and pharmaceutical industry should exercise due diligence in the promotion and usage of drugs that are used for medical abortion.[8] Despite this, it has been perceived by the society that medical abortions are extremely safe even in hands of untrained personnel, leading to overthe-counter dispensing and possible increase in unsupervised terminations of pregnancy and life-threatening complications.[9] In the present study, we want to highlight 
the consequences of self-medication of these abortifacient agents. The term self-medication is applied when patient, her husband, her friend or her relative has bought the abortifacient agents (for the patient) over-the-counter without medical guidance/ supervision/ prescription.

\section{MATERIALS AND METHODS}

After obtaining ethical committee clearance, an observational study was conducted at Midnapore Medical College, Midnapore from January 2016 to June 2017 for 18 months. The study was conducted with the objective of studying various demographic features, clinical features at presentation, complications, management of the study women received, maternal morbidity and mortality as a consequence of self-medication of abortifacient agents.

Total 102 women who were admitted in our department through emergency or outpatient department (OPD) with various clinical features after consumption of abortifacient agents purchased by self/ husband/ relative over-the-counter without medical guidance/ supervision/ prescription were included in the study. Women who had consumed abortifacient agents after consulting a registered medical practitioner and reported to us with complications and women who have undergone any surgical intervention after pill consumption in other health care centres before reporting to this medical college were excluded from this study. Detailed history regarding previous pregnancies, gestational age at which abortifacient agents were consumed and on admission complaints was noted. On admission detailed general survey, systemic and obstetrics examination were done in all patients. Routine blood investigation, particularly haemoglobin $(\mathrm{Hb} \%)$ was done in all cases and pelvic ultrasonography (USG) was done where indicated. Features of sepsis, shock, acute abdomen and severity of pallor were noted. Management of all the complications, intensive care unit (ICU) admissions, need for blood and blood product transfusions were recorded. Development of complications such as disseminated intravascular coagulation (DIC), acute renal failure, septicaemia and maternal death were also noted. All the data was entered as percentage or mean $\pm \mathrm{SD}$ as applicable.

\section{RESULTS}

Among 102 patients, $63(61.7 \%)$ were within 25 yrs. and 31 (30.4\%) were between $26-30$ yrs. of age (Table 1). There were 11 primigravida (10.8\%), 47 second gravida (46\%) and 44 women $(43.2 \%)$ had obstetric score of gravida 3 or more. 46 cases (45\%) had consumed pills before 7 weeks of gestation and 56 patients (55\%) had consumed between 7 and 12 weeks of pregnancy.

Excessive bleeding per vagina $(\mathrm{P} / \mathrm{V})$ with pain in lower abdomen (73.5\%) was the most common presenting symptoms followed by passage of fleshy mass (products of conception) in $12.7 \%$ of the cases. 12 cases $(11.7 \%)$ attended emergency as their USG report revealed retained products of conception. Two patients were brought to emergency with features of severe circulatory shock and pallor and clinically diagnosed as ruptured ectopic pregnancy after confirming positive urine for pregnancy test (Table 2).

All the cases were subjected to routine blood including $\mathrm{Hb} \%$ examination immediately after admission. Almost 85\% women were suffering from anaemia. Among them 9 patients
(8.8\%) were suffering from severe anaemia and 6 patients (5.6\%) were diagnosed to have very severe anaemia.[10] All those 15 patients required multiple units of blood and blood products transfusion (Table 3 ).

Out of total 102 cases, 80 patients were subjected to USG examination after admission. 2 cases were clinically diagnosed as ruptured ectopic pregnancy. Incomplete abortion was clinically diagnosed in 8 patients and as they were bleeding severely they were not subjected to USG examination (Table 4).

In cases with incomplete abortions and missed abortions, instrumental evacuation was done. Patients with ruptured ectopic pregnancy had undergone emergency laparotomy and salpingectomy. Those 2 patients received multiple blood product transfusions and also were on critical care support.

\begin{tabular}{|c|c|c|}
\hline Age Distribution (In Years) & Number & Percentage \\
\hline$\leq 19$ & 16 & 15.7 \\
\hline $20-25$ & 47 & 46 \\
\hline $26-30$ & 31 & 30.4 \\
\hline $31-35$ & 5 & 4.9 \\
\hline$\geq 36$ & 3 & 3 \\
\hline Total Table 1. Age Distribution \\
\hline \multicolumn{2}{|c|}{} \\
\hline \multicolumn{2}{|c|}{} \\
\hline
\end{tabular}

\begin{tabular}{|c|c|c|}
\hline Clinical Features at Presentation & No. & $\%$ \\
\hline Excessive bleeding $\mathrm{P} / \mathrm{V}$ with pain abdomen & 75 & 73.5 \\
\hline $\begin{array}{l}\text { Passage of products of conception (fleshy mass } \\
\text { expulsion) }\end{array}$ & 13 & 12.7 \\
\hline Ultrasound report of retained products & 12 & 11.7 \\
\hline Shock/features of ruptured ectopic pregnancy & 2 & 1.9 \\
\hline Total & 102 & 100 \\
\hline
\end{tabular}

\begin{tabular}{|c|c|c|}
\hline Hb\% (g/dL) & Number & Percentage \\
\hline$\geq 11$ & 15 & 14.7 \\
\hline $10-10.9$ & 51 & 50 \\
\hline $7-9.9$ & 21 & 20.9 \\
\hline $4-6.9$ & 9 & 8.8 \\
\hline$\leq 4$ & 6 & 5.6 \\
\hline Total & $\mathbf{1 0 2}$ & $\mathbf{1 0 0}$ \\
\hline Table 3. Hb\% (g/dL) on admission (WHO 2011) \\
\hline
\end{tabular}

\begin{tabular}{|c|c|c|}
\hline Ultrasound Findings & Number & Percentage \\
\hline Incomplete abortion & 57 & 55.9 \\
\hline Complete abortion & 15 & 14.7 \\
\hline Missed abortion & 5 & 4.9 \\
\hline Live gestation & 3 & 2.9 \\
\hline $\begin{array}{c}\text { Not subjected to USG } \\
\text { examination }\end{array}$ & 22 & 21.6 \\
\hline Total & 102 & 100 \\
\hline
\end{tabular}

\begin{tabular}{|c|c|c|c|c|}
\hline & $\begin{array}{c}\text { Thaker } \\
\text { et al(1) }\end{array}$ & $\begin{array}{c}\text { Bajwa } \\
\text { et al(9) }\end{array}$ & $\begin{array}{c}\text { Sarojini } \\
\text { et al(11) }\end{array}$ & $\begin{array}{c}\text { Present } \\
\text { Study }\end{array}$ \\
\hline $\begin{array}{c}\text { No. of } \\
\text { patients } \\
\text { and study } \\
\text { period }\end{array}$ & $\begin{array}{c}37 \text { women/ } \\
1 \text { year }\end{array}$ & $\begin{array}{c}260 \\
\text { women/ } \\
2 \text { years }\end{array}$ & $\begin{array}{c}104 \\
\text { women/ } \\
2 \text { years }\end{array}$ & $\begin{array}{c}102 \\
\text { women/18 } \\
\text { months }\end{array}$ \\
\hline $\begin{array}{c}\text { Presenting } \\
\text { complaint }\end{array}$ & $\begin{array}{c}\text { Bleeding } \\
\text { P/V }\end{array}$ & & $\begin{array}{c}\text { Bleeding } \\
\text { P/V } \\
69.1 \%\end{array}$ & $\begin{array}{c}\text { Bleeding } \\
\text { P/V with } \\
\text { pain } \\
\text { abdomen } \\
73.5 \%\end{array}$ \\
\hline
\end{tabular}




\begin{tabular}{|c|c|c|c|c|}
\hline $\begin{array}{l}\text { Ultrasound } \\
\text { findings }\end{array}$ & \begin{tabular}{|c|} 
Incomplete \\
abortion \\
$70.2 \%$ \\
\end{tabular} & \begin{tabular}{|c|} 
Incomplete \\
abortion \\
$41.5 \%$ \\
\end{tabular} & \begin{tabular}{|c|} 
Incomplete \\
abortion \\
$72.2 \%$ \\
\end{tabular} & \begin{tabular}{|c|} 
Incomplete \\
abortion \\
$55.9 \%$ \\
\end{tabular} \\
\hline $\begin{array}{c}\text { Instru- } \\
\text { mental } \\
\text { evacuation }\end{array}$ & $75.6 \%$ & & $90.4 \%$ & $83 \%$ \\
\hline $\begin{array}{c}\text { Ectopic } \\
\text { pregnancy }\end{array}$ & $5.4 \%$ & $1.15 \%$ & $1.9 \%$ & $1.9 \%$ \\
\hline Shock & $5.4 \%$ & nil & $2.9 \%$ & $1.9 \%$ \\
\hline Sepsis & $8.1 \%$ & $6.54 \%$ & $4.8 \%$ & Nil \\
\hline Death & $2.7 \%$ & nil & $1.9 \%$ & Nil \\
\hline
\end{tabular}

\section{DISCUSSION}

Present study highlights the consequences of self-medication of abortifacient agents. All women in this study easily procured the drug over the counter at local pharmaceutical shops without any premedication check-up by gynaecologists or RMP recognised for performing MTP. As per WHO recommendations, medical abortion are restricted upto 7 weeks, but unfortunately in our study $>55 \%$ women had consumed the pills beyond the recommended period of gestation.

In this study, $46 \%$ women were gravida 2 and $43.2 \%$ were gravida 3 or more. This indicates the abortifacient agents were consumed to get rid of unwanted pregnancy. Similar observation was reported by Sarojini et al.[11]

In our study, most common clinical presentation was bleeding $\mathrm{P} / \mathrm{V}$ associated with pain in lower abdomen (73.5\%). Similar observation was made by Sarojini et al (69.3\%) and Thacker et al (89\%).[1,11]

On ultrasound examination only $14.7 \%$ had complete abortion, whereas remaining $85.3 \%$ had incomplete abortion, missed abortion, continuation of pregnancy or ruptured ectopic. Three cases were diagnosed as live foetus by USG, but after counselling regarding teratogenic effect of abortifacient drugs all women agreed for surgical evacuation. All cases USG diagnosed complete, incomplete and missed abortions as well as 8 clinically diagnosed cases of incomplete abortion had undergone instrumental evacuation.

There were 2 cases of ruptured ectopic pregnancy. Both patients were $2^{\text {nd }}$ gravida with previous full term vaginal delivery. One of the patients had undergone surgical evacuation by a local untrained person suspecting a case of incomplete abortion. Both patients were in 8 weeks of gestation and had neither undergone clinical examination nor USG evaluation before consumption of pills for medical abortion. Incidence of ectopic pregnancy (1.9\%) reported by Sarojini et al is similar to present study.[11]

Incidence of anaemia (75\%) reported by Sarojini et al is similar to present study (85\%). Fortunately, in our study only $15 \%$ women received blood transfusion, whereas $52 \%$ women had received one unit blood transfusion and 23\% women were administered more than one unit in the study conducted by Sarojini et al.[11]

In a study conducted on 80,000 patients over 18 months, only $0.01 \%$ patients required blood transfusion when the drugs were given under medical supervision.[12] No patient required blood transfusion when drugs were given under medical supervision in a study conducted by Deshpande et al.[13]

Table 5 compares present study with previous studies. All the four studies show comparable results.

\section{CONCLUSION}

Health care and health protection is every woman's right. All women should be counselled regarding advantages, drawbacks, risks and limitations of different methods of abortion. Government must stop over-the-counter sale of drugs that are used for medical abortion. Drugs should be made available via health care facilities under supervision to reduce maternal morbidity and mortality due to indiscriminate use of abortifacient pills. Training on various regimens for medical abortion and advancement is also required for medical practitioners who are qualified under the MTP Act. In the event of suspicion of ectopic pregnancy on clinical examination, ultrasound examination is recommended prior to administration of abortifacient pills. Prevention of unwanted pregnancy is the best way to prevent unsafe abortion. Hence, awareness on contraceptives and emergency contraception should be encouraged.

\section{REFERENCES}

[1] Thaker RV, Deliwala KJ, Shah PT. Self-medication of abortion pill: women's Health in Jeopardy. NHL J Med Sci 2014;3(1):26-31.

[2] http://www.mohfw.nic.in/index1.php? Sublinkid=361\&level=3\&lid=2597\&Lang=1.

[3] Chaudhuri SK. Pregnancy termination. In: Practice of fertility control: a comprehensive manual. $7^{\text {th }}$ edn New Delhi: Elsevier 2007: p. 237-63.

[4] Ellertson C, Waldman SN. The mifepristonemisoprostol regimen for early medical abortion. Curr Women Health Rep 2001;1(3):184-90.

[5] International Concensus Conference on Non-surgical (Medical) abortion in early first trimester on issues related to regimens and service delivery. Frequently asked clinical questions about medical abortion. Geneva: World Health Organization 2006. ISBN 92-4159484-5.

[6] Kapur K, Joneja GS, Biswas M. Medical abortion-an alternative to surgical abortion. MJAFI 2006;62(4):351-3.

[7] Coyaji K. Early medical abortion in India: three studies and their implications abortion services. J Am Med Womens Assoc (1972) 2000;55(Suppl 3):191-4.

[8] http://www.fogsi.org/index.php?option=com_content \&view=article\&id=97\&Itemid=16.

[9] Bajwa SK, Bajwa SS, Ghai GK, et al. Medical abortion: Is it a blessing or curse for the developing nations? Sri Lankan J Obstet \& Gynaecol 2012;33(3):84-90.

[10] World Health Organization: Haemoglobin concentrations for the diagnosis of anaemia and assessment of severity. Vitamin and mineral nutritional information system. World Health Organization Geneva, 2011.

[11] Sarojini, Ashakiran TR, Bhanu BT, et al. Over the counter MTP pills and its impact on women's health. J Obstet Gynaecol India 2017;67(1):37-41.

[12] Hausknecht R. Mifepristone and misoprostol for early medical abortion: 18 months experience in United States. Cotraception 2003;67(6):463-5.

[13] Deshpande S, Yelikar K, Deshmukh A, et al. Comparative study of medical abortion by mifepristone with vaginal misoprostol in women $<49$ days versus 50-63 days of amenorrhoea. The J Obstet Gynaecol India 2010;60(5):403-7. 